\title{
Social Inclusion, Innovation and Food Security in West Africa
}

\author{
Muhammad Khalid Anser ${ }^{1}$, Danish Iqbal Godil ${ }^{2}$, Busayo Aderounmu ${ }^{3,4}$, Ademola Onabote ${ }^{4,5, *(D)}$, \\ Romanus Osabohien ${ }^{3,4, * \mathbb{D}}$, Junaid Ashraf ${ }^{6}$ id and Michael Yao-Ping Peng $7, * \mathbb{D}$
}

1 School of Public Administration, Xi'an University of Architecture and Technology, Xi'an 710000, China; khalidsnnu@yahoo.com

2 Business Studies Department, Bahria Business School, Bahria University, Karachi Campus 75260, Pakistan; danishiqbal.bukc@bahria.edu.pk

3 Department of Economics and Development Studies, Covenant University, Ota 112212, Nigeria; busayo.aderounmu@covenantuniversity.edu.ng

4 Centre for Economic Policy and Development Research (CEPDeR), Covenant University, Ota 112212, Nigeria

5 Department of Economics, Landmark University, Omu-Aran 251101, Nigeria

6 School of Statistics, Jiangxi University of Finance and Economics, Nanchang 330013, China; junaidashraf2020@outlook.com

7 School of Economics and Management, Foshan University, Foshan 528000, China

* Correspondence: onabote.ademola@lmu.edu.ng (A.O.); romanus.osabohien@covenantuniversity.edu.ng (R.O.); s91370001@mail2000.com.tw (M.Y.-P.P.)

Citation: Khalid Anser, M.; Iqbal Godil, D.; Aderounmu, B.; Onabote,

A.; Osabohien, R.; Ashraf, J.; Yao-Ping

Peng, M. Social Inclusion, Innovation and Food Security in West Africa. Sustainability 2021, 13, 2619. https:// doi.org/10.3390/su13052619

Academic Editor: Sara González García

Received: 19 January 2021

Accepted: 24 February 2021

Published: 1 March 2021

Publisher's Note: MDPI stays neutral with regard to jurisdictional claims in published maps and institutional affiliations.

\begin{abstract}
To achieve the United Nations Sustainable Goals (SDGs) by 2030, especially goal 2 (SDG-2) which is to "end hunger, achieve sustainable food security, improved nutrition and promote agriculture" this study examines how innovation and social inclusion affect food security in West Africa. The study applies the system Generalised Method of Moments (GMM) on a panel data of 15 West African countries for the period 2005-2018. The result from system GMM shows that innovation and social inclusion are drivers of food security. The implication of this is that increased level of social inclusion and innovation in West African may increase the level of food security by about $41.5 \%$ and $13.6 \%$ respectively. Therefore, the study concludes that to feed the growing African population, social inclusion should be improved to mitigate risk, vulnerability and socioeconomic shocks faced by farming households. In addition, innovation in agricultural should be enhanced to drive productivity, thereby leading to a sustainable food security.
\end{abstract}

Keywords: food security; sustainability; innovation; social protection; social inclusion; SDG-2

\section{Introduction}

Africa has drawn global attention because of its various accomplishments and its dynamism. Irrespective of these attainments, the continent has also drawn global attention for its considerable problems such as social exclusion, food insecurity, poverty, inequality and unemployment, among others [1]. Undernourishment and poverty have been reduced significantly and the aftermath development is positive. The dynamic social drive is aiding in transforming villages and creating awareness of initially neglected problems, and households and recent programmes and strategies across the continent have underscored the significance of social inclusion [1]. The increase in the population growth rate has been recognised as one reason for increased food insecurity and slow economic growth in Africa.

Africa is expected to experience a substantial population increase by 2050, doubling its current population of 1.2 billion to more than 2 billion. Considering that current food production practices employed across the continent are unsustainable, Africa is missing an opportunity to be self-sustaining, and even export food [1]. Furthermore, climate change disproportionally affects the continent, making the need for transformation even more urgent. If Africa is to mitigate these roadblocks, agriculture needs to be modernised through the contributions of different technologies [2]. 
Innovations comprise of an improvement in technology such as artificial intelligence (AI), blockchain technologies, mobile application, the internet of things (IoT), big data, and drones [3]. Innovation has the potential of providing revolutionary methods of production and distribution based on digital transformation and automation that can erase limits between physical objects, turning them into a comprehensive, complex system of interconnected and interdependent elements [3]. Hence, these technologies have the potential to have a positive effect on the productivity and profitability of the agricultural sector and the creation of new locally-based added value, especially in Africa [3]

The World Bank [3] posits that the proportion of the people in Africa who are living in extreme poverty and undernourishment has reduced considerably from about $57 \%$ in 1990 to about $41 \%$ in 2013 [3-6]. Nevertheless, the largest share of the extreme global poor and undernourished people still live in Africa [4]. Approximately 390 million people in Africa lived in extreme poverty (less than \$1.25 daily) in 2013, more than all other regions combined [4]. Lastly, the region not only houses the largest number of the poor, but Africa's poor are, on average, living much further below the poverty line [3,7].

In the last two decades, Africa has witnessed a reasonable level of social inclusion, in some aspects moving at a rate faster than seen globally $[3,6]$, though a larger number of individuals, households, communities and areas have been ignored by the achievements of Africa's social inclusion and as a result, continue to be at risk. This exclusion has led to the challenge of food insecurity in Africa. Food security is one of the world's major goals, especially, with respect to the achievement of the 2030 sustainable development goals, particularly, Goal 2 (SDG-2), which is to end extreme hunger and achieve food security. To achieve a sustainable food security, it is necessary to implement appropriate policies to capture all households' including the very poor and the marginalised people, especially, those in the rural areas [5]. This study argues that one of the best approaches to ensure that all households are captured with food security is the improvement of social inclusion policies mainly targeted at the most vulnerable individuals.

In the last two decades, social inclusion programmes have helped raise about 150 million people out of extreme poverty and improve food security. However, less than $50 \%$ of the global population is effectively covered by at least one social benefit, in particular, farmers in rural communities in Africa, lack social inclusion coverage to mitigate risk and socio-economic shocks. Though empirical studies have looked at social inclusion, poverty, livelihood and food security, the context of how social inclusion and innovation drive food security in West Africa, has not been given much attention in the literature, to the best of authors' knowledge. Against this background, this study examines how social inclusion (proxied by the policy for social inclusion) and innovation (proxied by mobile subscription, $\%$ of the total population) affect food security in West Africa. The study applied the system GMM to achieve this objective. This study is structured into five sections. Following this introductory section is a review of the literature, presented in Section 2. Section 3 is the methodology; results are presented and discussed in Section 4, while the study concludes with Section 5 .

\section{Literature Review}

\subsection{Social Inclusion, Agriculture and Food Security}

According to [8], "social inclusion is a process of improving the terms for individuals and groups to take part in society, and the process of improving the ability, opportunity, and dignity of people, disadvantage based on their identity, to take part in society". Social inclusion, a multifaceted process seeks to ensure that all nations and people are liberated from poverty and hunger while improving their access to better living conditions [9].

Jolley et al. [10], in a study of social inclusion among people living with disabilities in five West African countries of Senegal Sierra, Leone, Mali, Liberia and Cameroon, observed that women, older people and individuals with low-income among others are found to be predominantly afflicted with impairment as a result of increasing risk to health and inadequate access to health-care facilities. In addition, Jolley et al. [10] found that, while 
virtually all countries in the study have established a new measure in terms of policies and regulations to help the disadvantaged group, however, the execution is problematic. This is because institutional framework, such as government effectiveness and corruption control, are critical requirements for the most vulnerable households to be appropriately captured. In most cases, especially in Africa, institutional quality acts as bane on the effective delivery of social inclusion.

Food security means the accessibility and availability of food to all households [11], and it is an integral part of human existence. The study by [12] acknowledged food security as a national threat that must be given a significant priority. The study by [13] posited that a regional food reserve programme has been initiated in the West African region since 2010. The study applied a spatial equilibrium model to examine the effects of food reserve in a shock to production process. Result of the effect scenario shows that a production shock affects price, importation and ultimately, food product consumption. This situation is not favourable to the West African and should be checked by increasing the minimum reserve size.

Hidrobo et al. [14] focused on how social protection contributes to food security and asset formation in Africa. Food security measures are divided into six groups, while the asset formation measures are divided into five groups using the meta-analysis technique. Meanwhile, Subramaniam et al. [15] posits food insecurity as a significant problem in the world since a considerable population of people worldwide are believed to suffer from malnutrition due to the absence of enough food. This research examines 51 developing countries with data for six years ranging from 2011-2016. This method of analysis used is the generalised panel method of moments (GMM) while the aim was to examine the effect of biofuel production on food security in the selected 51 countries. The study found convincing evidence that biofuel worsens food security in developing countries. In another similar study Osabohien et al. [16], the GMM was applied and it was found that social protection intervention in agricultural led to increased level of participation, thereby leading to an improved level of productivity in Africa.

The relationship between community social interaction, households' food security and income are investigated by [17]. Having indicated food insecurity as a significant health concern; social capital is seen as mitigation of food insecurity in the world, the study by [17] used a cross-sectional survey and questionnaires and engaged Tobit regression analysis to analyses the relationship between community social interactions and household's food security. The results did not find any evidence that the lower-income community gained more than a higher-income community from social interaction. Furthermore, a significant number of the older community contribute more to household food security; therefore, encourage the use of policies that facilitate food security and accessibility while promoting social interactions.

\subsection{Innovation, Agriculture and Food Security}

Because of the many problems facing the world, such as hunger, rising unemployment and food and nutritional insecurity, and in an attempt to close the huge-gap between the supply of and the demand for food by 2050, the Food and Agriculture Organisation (FAO) has established that a 70\% rise in food production is necessary to bridge this gap [7]. However, this can only be done by incorporating agricultural innovation into the scale-up production process.

To raise agricultural production, which is necessary to feed the global population by 2050, the application of technological innovation is vital [7]. FAO [7] defines agricultural innovation as the process whereby individuals or organisations bring new or existing products, processes or ways of an organisation into use for the first time in a specific context in order to increase effectiveness, competitiveness, resilience to shocks or environmental sustainability and thereby contribute to food security and nutrition, economic development or sustainable natural resource management. 
In a study by [18] food insecurity may easily be tackled through the introduction of innovation and technology in the agricultural sector, to scale-up production. The role of innovation in improving food cultivation cannot be ignored. This is because, the application of technology could potentially reduce the cost of production [19]. A labour-intensive economy is needed for the cultivation of more food to help contribute to food security. According to [20], innovation is a global phenomenon, affecting all economic sectors, particularly food and agriculture, which are one of the oldest and most important sectors in the world. The study shows how technology can increase food yield and address other related challenges affecting the agricultural sector. A global innovation index which serves as a global measurement of innovation was also calculated with six significant findings.

African has witnessed a surge in its population growth rate in recent time, according to [21]. This phenomenon is associated with an increase in the number of undernourished people in African. Bettencourt and West [22] investigated the relationship between agricultural innovation and food security in the Sub-Saharan African (SSA). A range of initiatives has been taken by the region to produce enough food and guarantee food security. Worthy of consideration is the incorporation of biotechnology, which has been identified to alleviate some of the region's food security issues. The study observed that although there have been some innovative advancements in recent times, food production is minor.

The study by Di Vaio et al. [23], argued that the application of innovative technologies, such as artificial intelligence (AI) among others, as a sustainable business model (SMB) in the agri-food system, has the potential to drive food security. The study engaged a qualitative method and an in-depth review of the literature and concludes that, innovative approach in agriculture will enhance an efficient value chain in agri-food industry. The study also states that the outbreak of COID-19 pandemic awakes the need for urgent application of innovative technology in agri-food system to build an efficient value chain. This is because, innovative technologies provide a more significant outcomes needed to generate relevant information that could have a significant impact on business models.

On the hand, Grieve et al. [24] identified a number of threats (such as population growth, ageing farming populations and climate change) to global food security. However, caution must be observed while encouraging the use of AI to achieve sustainable food security, so as not to endanger food safety [25]

\section{Methodology}

\subsection{Model Specification}

A large proportion of the African population has been excluded from social safety net programmes, as a result of the weak institutional framework, which has resulted in poverty and food insecurity among the less the privileged $[6,21,26]$. The objective of this study is to examine how social inclusion affects food security in West Africa. The study engaged a panel data of 15 West African countries that are members of the Economic Community of West African States (ECOWAS). Drawing insight from the empirical work of [23] and [16], the estimated models (in double-log form) are specified in Equations (1) and (2):

$$
l F S_{i t}=\alpha_{0}+\alpha_{1} l S I_{i t}+\alpha_{2} l I N O V_{i t}+\alpha_{3} l A E_{i t}+\alpha_{4} l C C_{i t}+\alpha_{5} l G E_{i t}+\alpha_{6} l F D I_{i t}+e_{i t}
$$

where, FS is food security (the dependent variable); INOV means innovation, SI means social inclusion, $A E$ means employment in agriculture, $C C$ means control of corruption, $G E$ means government effectiveness, FDI means foreign direct investment while, $l$ represents natural logarithm of the variables. The variables in the model are in their natural logarithm reduce the incidence of heteroscedasticity. Equation (1) is estimated using the Pooled Ordinary Least Squares (POLS) regression, and the Fixed effect model.

To control for unobserved heterogeneity and potential endogeneity of the exogenous variables, the system GMM approach is applied [26-28] as shown in Equation (2):

$$
l F S_{i t}=\alpha_{0}+\varphi l F S_{i t-1}+\alpha_{1} l S I_{i t}+\alpha_{3} l I N O V_{i t}+\alpha_{3} l A E+\alpha_{4} l C C+\alpha_{5} l G E_{i t}+\alpha_{6} l F D I_{i t}+e_{i t}
$$


In the model, $l F S_{i t-1}$ means the first-lag of the dependent variable (food security), $\varphi$ is the coefficient of first-lag of food security, $\alpha_{0}$ is constant term; $\alpha_{1}, \alpha_{2}, \alpha_{3}, \alpha_{4}, \alpha_{5}$ and $\alpha_{6}$ and are the coefficients of the explanatory variables. Equation (2) is estimated using the system GMM.

The 'a priori' expectation is that the estimated coefficient of explanatory variables should be significant and positively related to food security. In the model, $e$ represents the white noise, which captures other explanatory variables not included. Also, it represents entities and time, respectively. Time means the years (2005-2018), while entities represent the 15 West African countries considered in the study.

\subsection{Sources of Data and Measurement of Variables}

The study used a panel data of 15 West African countries which are members of the Economic Community of West African States (ECOWAS). The data was sourced from the World Development Indicators (WDI), the Country Policy and Institutional Assessment (CPIA), and the World Governance Indicators (WGI) of the World Bank. The summary of variables and their respective sources is presented in Table 1.

Table 1. Summary of Data sources and Measurement of Variables.

\begin{tabular}{ccccc}
\hline Variable & Identifier & Measurement & Source \\
\hline Food Security & FS & Food Production index & WDI \\
\hline Social inclusion & SI & Scale of 1 (lowest) to 6 (highest). The higher, the better. & CPIA \\
\hline Innovation & INOV & Mobile internet subscription (\% of total population) & WDI \\
\hline Agricultural employment & AE & Employment in agriculture (\% of total employment) & (modelled ILO estimate) & WDI \\
\hline Gontrol of Corruption & CC & $\begin{array}{c}\text { Estimate of standard normal distribution. Ranges from } \\
-2.5 \text { (lowest) to 2.5 (highest). The higher the better }\end{array}$ & WGI \\
\hline Foreign Direct Investment & GE & $\begin{array}{c}\text { Estimate of standard normal distribution. It ranges from } \\
-2.5 \text { (lowest) to 2.5 (highest). The higher, the better }\end{array}$ & WGI \\
\hline Note: CPIA ment Effectiveness & FDI & Foreign direct investment, net inflows (\% of GDP) & WDI
\end{tabular}

Note: CPIA means Country Policy and Institutional Assessment. WDI means World Development Indicators. WGI Means World Governance Indicators. Source: Authors.

The variables used for the analysis are food security (FS), measured by the food production index, which covers food crops that are considered edible and contain nutrients, innovation $(I N O V)$, imeasured by mobile internet subscriptions (\% of the population using the internet), sourced from the World Development Indicators (WDI) of the World Bank. Social inclusion (SI) is proxied by the policy for social inclusion and equity coverage, sourced from the Country Policy and Institutional Assessment (CPIA). Social inclusion policy includes gender equality, equity of public resource use, building human resources, social protection and labour, and policies and institutions for environmental sustainability [29]. Social inclusion is measured on a scale of 1 (lowest) to 6 (highest). A score of 1 to 2 (lowest) means a situation where individuals in a country have very low access to social inclusion or protection benefits. A score of 3 to 4 (moderate) means the condition where individuals in a country have a moderate access to social inclusion benefits, and a score of 5 to 6 (highest) means a condition where citizens have the highest access to social inclusion benefits. Social inclusion or protection benefits include social insurance (e.g., health insurance), social security (e.g., in-kind and cash support for farmers, senior citizens (the aged) and the most vulnerable), and labour market intervention (e.g., unemployment benefits). Developed countries such as most countries in America and Europe are operating at a scale of 5 to 6, while developing countries, like Countries in Africa, are operating at a scale of 1 to 2 , or at the very best, 3 . 
Agricultural employment (AE) is measured by employment in agriculture (\% of total employment, modelled ILO estimate), sourced from World Development Indicators (WDI) of the World Bank.

Control of Corruption (CC) and Government effectiveness (GE) are measures of institutional quality, sourced from the World Governance Indicators (WGI). Control of Corruption captures perceptions of the extent to which public power is exercised for private gain [29]. Government effectiveness is the perception of the quality of public services, the quality of the civil service and the degree of its independence from political pressures, the quality of policy formulation and implementation, and the credibility of the government's commitment to such policies [29]. Foreign Direct Investment Foreign (FDI) is measured by net inflows (\% of GDP), sourced from the World Development Indicators (WDI). The variables used are summarised in Table 1.

\section{Results and Discussion}

\subsection{Descriptive Statistics and Correlation Analysis}

Table 2 shows the descriptive statistics of the variables used in this study. Food security shows as the average of 122.96 in West Africa during the study period, social inclusion shows an average of 3.28 . The average of employment in agriculture is $51.59 \%$. This implies that the agricultural sector in West Africa contributes about 51.59\% to total employment. This value validates the importance of agriculture, especially employment creation in the sub-region. In a similar way, the percentage mean of innovation and foreign direct investment are $55.89 \%$ and $4.95 \%$ respectively. However, government effectiveness and control of control are both negative with an average value of -0.77 and -0.61 , respectively.

Table 2. Descriptive Statistics.

\begin{tabular}{cccccccc}
\hline & FS & SI & INOV & GE & FDI & AE & CC \\
\hline Mean & 122.9613 & 3.278571 & 55.89988 & -0.771516 & 4.953100 & 51.59232 & -0.614802 \\
Maximum & 201.2200 & 4.300000 & 138.8100 & 0.353523 & 32.30119 & 77.99800 & 0.950176 \\
Minimum & 75.58000 & 2.200000 & 2.070000 & -1.642998 & -1.048196 & 29.65200 & -1.552299 \\
Std. Dev. & 22.56817 & 0.458864 & 34.75339 & 0.454421 & 5.864468 & 14.60796 & 0.551200 \\
\hline
\end{tabular}

Source: Authors' compilation.

The correlation matrix between variable was displayed in Table 3 . The highest statistic is 0.89 , which is found between government effectiveness and control of corruption. The high, and positive, the correlation between these variables indicate that combination to achieve effective and efficient governance in the economy.

Table 3. Correlation Matrix.

\begin{tabular}{cccccccc}
\hline & FS & SI & INOV & GE & FDI & AE & CC \\
\hline FS & 1 & & & & & & \\
SI & -0.0263 & 1 & & & & & \\
INOV & 0.3698 & 0.2742 & 1 & & & & \\
GE & -0.1789 & 0.8318 & 0.2384 & 1 & & \\
FDI & 0.3245 & 0.0618 & -0.037 & -0.0754 & 1 & & \\
AE & 0.1949 & -0.275 & -0.3955 & -0.2442 & 0.3466 & 1 & \\
CC & -0.1673 & 0.8274 & 0.258 & 0.8906 & -0.0587 & -0.2447 & 1 \\
\hline Source: Authors' $^{\text {compilation. }}$
\end{tabular}

Source: Authors' compilation.

\subsection{Estimates from POLS and Fixed Effects}

To examine the effect of social inclusion and innovation on food security, this study carried out a POLS and fixed effects analysis. As presented in Table 4, the results show that R-squared is approximately 0.80 , which implies that the explanatory power of the model explains about $80 \%$ of the variations in food security in West Africa. Social inclusion is positive and significantly influences food security. There is an average of $48 \%$ responsiveness of food security to a percentage increase in social inclusion policy in all the equations. 
This is in line with the study of [17] which found that policy for social inclusion plays a significant role in curbing food insecurity in Africa. This implies that enforcement of policy for social inclusion is bound to increase food security since the policy is basically based on eliminating poverty and hunger and improving people's living condition.

Table 4. Pooled Ordinary Least Squares Result (Dependent variable: Food Security).

\begin{tabular}{|c|c|c|c|c|}
\hline Variables & 1 & 2 & 3 & 4 \\
\hline Constant & $\begin{array}{c}-154.62 * \\
(0.000)\end{array}$ & $\begin{array}{c}-143.96 \text { * } \\
(0.000)\end{array}$ & $\begin{array}{c}-164.90 * \\
(0.000)\end{array}$ & $\begin{array}{c}-148.42 \text { * } \\
(0.000)\end{array}$ \\
\hline Social Inclusion & $\begin{array}{l}47.99 * \\
(0.000)\end{array}$ & $\begin{array}{l}47.88 * \\
(0.000)\end{array}$ & $\begin{array}{l}48.25 * \\
(0.000)\end{array}$ & $\begin{array}{l}\mathrm{d} 47.86 \text { * } \\
(0.000)\end{array}$ \\
\hline Innovation & $\begin{array}{l}5.16 * \\
(0.004)\end{array}$ & $\begin{array}{c}5.43^{*} \\
(0.004)\end{array}$ & $\begin{array}{c}4.90 * \\
(0.006)\end{array}$ & $\begin{array}{l}5.10 * \\
(0.005)\end{array}$ \\
\hline Government Effectiveness & $\begin{array}{c}1.17 \\
(0.520)\end{array}$ & & & \\
\hline Foreign Direct Investment & $\begin{array}{l}3.56 \text { ** } \\
(0.050)\end{array}$ & $\begin{array}{l}4.27^{* *} \\
(0.024)\end{array}$ & $\begin{array}{l}3.78 * * \\
(0.037)\end{array}$ & $\begin{array}{l}3.52 * * \\
(0.053)\end{array}$ \\
\hline Agriculture Employment & & $\begin{array}{c}-1.91 \\
(0.412)\end{array}$ & & \\
\hline Control of corruption & & & $\begin{array}{l}3.29 * * * \\
(0.083)\end{array}$ & \\
\hline R-squared & 0.8007 & 0.8030 & 0.8037 & 0.8003 \\
\hline $\mathrm{F}$ (stat) & 173.81 & 164.03 & 177.09 & 232.39 \\
\hline Prob $>$ F & 0.0 & 0.0000 & 0.0000 & 0.0000 \\
\hline
\end{tabular}

Innovation in the same vein, positively and significantly affect food security. The results in Table 4 show that innovation brings about approximately a 5\% (on average) increase in food security. This supports the assertions by $[18,20]$ that found that innovation reduces the cost of production, cost of food and food insecurity. Government effectiveness (1.17), and control of corruption (3.29) significantly affect food security. This implies that a percentage increase in government effectiveness and control of corruption increases food security by 1.17 and 3.29, respectively. This is in line with the findings by [30]. The meaning of this is that if the government is able to control corruption in the country, there will be proper and even distribution of income among the people, which gives the individual the opportunity to have access to and be able to afford food for daily consumption. This also addresses SDG 1, 2 and 9 in order to achieve sustainable development.

Foreign direct investment also positively and significantly (0.05) influence food security. A proportionate increase in foreign direct investment increases food security by 4 . This is contrary to [31] findings, whose findings established a negative relationship between FDI and food security. However, the study of [32] found that both negative and positive relationship exists in primary and secondary sectors, respectively. Thus, this study established the validity of modernisation theory that proposes that FDI results in improved technology, managerial skills, access to the international market, create industrialisation among others which will, in turn, lead to efficiency in production and allocation of resources.

On the contrary, employment in agriculture negatively and significantly influences food security. This implies that a proportionate increase in agriculture employment reduces food security by 1.91. This may be due to lack of motivation for people to participate in agricultural activities and the migration of people from rural areas (where agricultural activities are mainly done) to urban areas in search for greener pasture and amenities, which are not available in the rural areas.

This study further carried out a fixed effect method of estimation, based on Hausman result. As shown in Table 5, the result is similar to the POLS result presented in Table 4. Social inclusion also positively and significantly influences food security at a $1 \%$ level of significance. This implies that an improvement in or enforcement of social inclusion policy 
positively and significantly increases food security by approximately $48 \%$. Innovation also affects food security positively. Innovation reduces the cost of production and hunger by reducing food costs and making it affordable while also reducing unemployment and poverty. Foreign direct investment improves modernisation and access to the international market, which boost the local economy and eliminate food insecurity through the provision of modern equipment for the production of agricultural produce. The result shows that an increase in FDI increases food security by approximately $4 \%$ in all the equations analysed.

Table 5. Fixed Effect Result (Dependent variable: Food Security).

\begin{tabular}{|c|c|c|c|c|}
\hline Variables & 1 & 2 & 3 & 4 \\
\hline Constant & $\begin{array}{c}-164.44 * \\
(0.000)\end{array}$ & $\begin{array}{c}-153.82 * \\
(0.000)\end{array}$ & $\begin{array}{c}-161.88 \text { * } \\
(0.000)\end{array}$ & $\begin{array}{c}-145.42 \text { * } \\
(0.000)\end{array}$ \\
\hline Social Inclusion & $\begin{array}{l}47.70 * \\
(0.000)\end{array}$ & $\begin{array}{l}47.77^{*} \\
(0.000)\end{array}$ & $\begin{array}{l}47.65 * \\
(0.000)\end{array}$ & $\begin{array}{l}47.49 * \\
(0.000)\end{array}$ \\
\hline innovation & $\begin{array}{c}4.80 * \\
(0.008)\end{array}$ & $\begin{array}{l}4.77^{* *} \\
(0.013)\end{array}$ & $\begin{array}{c}4.51 * \\
(0.000)\end{array}$ & $\begin{array}{l}4.62 * \\
(0.001)\end{array}$ \\
\hline Government Effectiveness & $\begin{array}{l}4.43^{* * *} \\
(0.099)\end{array}$ & & & \\
\hline Foreign Direct Investment & $\begin{array}{l}3.89 * * \\
(0.048)\end{array}$ & $\begin{array}{l}3.57^{* * *} \\
(0.082)\end{array}$ & $\begin{array}{l}3.67^{* * *} \\
(0.062)\end{array}$ & $\begin{array}{l}3.45^{* * *} \\
(0.064)\end{array}$ \\
\hline Agriculture Employment & & $\begin{array}{c}1.85 \\
(0.40)\end{array}$ & & \\
\hline Control of corruption & & $\begin{array}{l}3.29 * * * \\
(0.083)\end{array}$ & $\begin{array}{c}3.67 \\
(0.213)\end{array}$ & \\
\hline R. squared & 0.80 & 0.80 & 0.81 & \\
\hline F-stat & 169.60 & 151.72 & 168.05 & 222.75 \\
\hline
\end{tabular}

Note: The $p$-values are in the parentis ()$,{ }^{*}, * *$, and ${ }^{* * *}$, means that the coefficient is significant at $1 \%, 5 \%$ and $10 \%$ level respectively.

The effect of government effectiveness on food security gives a positive and significant outcome at $10 \%$ level of significance, which implies that the institutional framework's effectiveness can help mitigate food insecurity. Control of corruption also plays a significant role in ensuring food security is attained. The result for control of corruption is significant across models, implying that controlling corruption in the economy is essential for food security. The positive coefficient (on average, 3 ) shows that curbing corruption increases food security by $3 \%$.

Employment in agriculture, on the other hand, was found to be insignificant. This may be as a result of the use of manpower in producing agricultural product may not bring about the desired outcome than making use of modern technology and equipment in facilitating agricultural production. In order to achieve food security in the countries, there is a need to promote the use of modern equipment like tractors, harvesters etc. on farmland than using manual labour.

\subsection{Estimates from System Generalised Method of Moments}

To control for the issues of endogeneity, the system generalised method of moments (GMM) is applied. One of the problems may be that it consists of the disturbance autocorrelation in the time-series regression analysis. Another econometric problem may be that the potential endogeneity of the key regressors may be present. This is because, [26] stated that variables that are not statistically significant in the linear static panel model might be due to the endogeneity problem.

The study, therefore, addresses this problem by using the system GMM method [27,33]. System GMM is a combination of level and difference dynamic equations that improves on difference GMM. This is because, it supplements the equation in the first differences with the equation in levels and allows for the correction of measurement errors in the other regressors [33]. The prerequisite for system GMM is that the autocorrelation at the 
first-order autoregressive AR (1) process should be significant and autocorrelation at the second-order autoregressive AR (2) should be insignificant. The Sargan test is insignificant, which means the instruments are not correlated with the residuals, and thus are valid (presented in Table 6).

Table 6. System GMM Result (Dependent variable: Food Security).

\begin{tabular}{ccccc}
\hline Variable & {$[1]$} & {$[2]$} & {$[3]$} & {$[4]$} \\
\hline Constant & $2.0853^{*}$ & $2.1309 *$ & $0.713744^{*}$ & $1.0606^{*}$ \\
& $(0.000)$ & $(0.000)$ & $(0.002)$ & $(0.000)$ \\
Food security $(-1)$ & $0.27062^{*}$ & $0.25584^{*}$ & $0.25467 *$ & $0.26773^{*}$ \\
& $(0.002)$ & $(0.008)$ & $(0.008)$ & $(0.004)$ \\
Social Inclusion & $0.46977^{*}$ & $0.56962 *$ & $0.41540^{*}$ & $0.67488^{*}$ \\
& $(0.000)$ & $(0.000)$ & $(0.000)$ & $(0.000)$ \\
Innovation & $0.13577^{*}$ & $0.14266^{*}$ & $0.15481 *$ & $0.15092^{*}$ \\
& $(0.000)$ & $(0.000)$ & $(0.000)$ & $(0.000)$ \\
Government Effectiveness & $0.12824^{*}$ & $0.16922 *$ & $0.18239 *$ & \\
Foreign Direct Investment & $(0.003)$ & $(0.000)$ & $(0.000)$ & \\
Agriculture Employment & & $0.03370 *$ & & \\
Control of corruption & & $(0.000)$ & & \\
& & & $0.288257 *$ & $0.28078^{*}$ \\
Group/Observation & & & $(0.000)$ & $(0.000)$ \\
Wald chi2 & $15 / 159$ & $15 / 159$ & $15 / 151$ & $15 / 151$ \\
& $299.74 *$ & $313.21 *$ & $386.49 *$ & $383.30 *$ \\
AR (1) & $(0.000)$ & $(0.000)$ & $(0.000)$ & $(0.000)$ \\
& $-3.97 *$ & $-3.89 *$ & $-3.76 *$ & $-3.98 *$ \\
AR (2) & $(0.000)$ & $(0.000)$ & $(0.000)$ & $(0.000)$ \\
Sargan Test & 1.63 & 1.71 & 1.44 & 1.96 \\
& $(0.104)$ & $(0.880)$ & $(0.151)$ & $(0.52)$ \\
& 2.18 & 4.95 & 4.14 & 1.94 \\
& $(0.336)$ & $(0.176)$ & $(4.14)$ & $(0.586)$ \\
\hline
\end{tabular}

Note: The p-values are in the parentis ( ), * means that the coefficient is significant at $1 \%$ level. Source: Authors.

The results presented in Table 6 show that across models, variables engaged for the system GMM analysis are statistically significant at the $1 \%$ level and positive in explaining the level of food security. The results show that an increased level of social inclusion may increase food security between $41.5 \%$ to $67.49 \%$. In the same vein, improvement in technological innovation may increase food security by at least $13.58 \%$. This supports the findings by [18] and [20] who found that innovation reduces production cost, cost of food and food insecurity. Similarly, the results show that a $1 \%$ increase in foreign direct investment and employment in agriculture may likely increase the level of food security by $3.37 \%$ and $28.83 \%$, respectively.

Institutional framework or quality measured by government effective and control of corruption is also positive and significant in determining the level of food security. In this wise, effectiveness in governance and the deployment of efficient mechanisms in controlling corruption will result in at least $12.82 \%$ and $25.01 \%$ increase in food security, which is in line with the findings by [26] using the system GMM. Also, it is in line with the findings by [30], showing that if the government can control corruption and improve governance, there will be proper and even distribution of income among the people, which gives an individual the opportunity to have access to and be able to afford food for daily consumption.

\section{Summary and Conclusions}

To achieve the United Nations Sustainable Goals (SDGs) by 2030, mainly, goal 1.3 which is to "implement efficient social inclusion (protection) schemes and achieve consid- 
erable coverage for the poor and the vulnerable", and goal 2; to "end extreme hunger and achieve sustainable food security" this study contributes to the literature by examining how innovation and social inclusion helps in enhancing agricultural productivity, thereby achieving sustainable food security.

The study engaged a panel data of 15 West African countries that are members of the Economic Community of West African States (ECOWAS). To control for unobserved heterogeneity and potential endogeneity of the exogenous variables, the system generalised method of moments (GMM) is applied. The data for the analysis was sourced from the Country Policy and Institutional Assessment (CPIA), World Development Indicators (WDI) and World Governance Indicators (WGI) of the World Bank for the period 2005-2018. Though the study engaged the POLS and fixed effect regression, due to possible issue of endogeneity that may be present in POLS and fixed effect estimates, inferences are drawn from the system GMM result.

Findings from the system GMM show that innovation and social inclusion are drivers of food security in West Africa. This is because an increased level of social inclusion and innovation in West Africa may increase the level of food security by $41.5 \%$ and $13.6 \%$. The institutional framework or quality measured by government effectiveness and control of corruption is also positive and significant in determining the level of food security. In this wise, effectiveness in governance and the deployment of efficient mechanisms in controlling corruption will result in at least $12.82 \%$ and $25.01 \%$ increase in food security.

The study concludes that to feed the growing African population, social inclusion should be improved to mitigate risk, vulnerability and socioeconomic shocks faced by farming households. In addition, innovation in agricultural should be enhanced to drive productivity, thereby leading to food security. However, this study is not without limitations.

Some of the limitations of this study are that: (a) the study engaged a panel data of 15 West African countries, therefore, did not account for the effect of social inclusion and innovation on food security at the country level, (b) due to data paucity, the study used mobile internet subscriptions (\% of total population) as a proxy for innovation, which may not reflect the exact proportion of internet services used for agricultural purposes, (c) the study used food production to capture food security, which may not be sufficient enough to capture all the dimensions (availability, accessibility, utilisation and stability) of food security.

Given data availability, further studies should focus on how social inclusion will help in building smallholder farmers' resilience against risk and socioeconomic shocks towards achieving a sustainable food security in West Africa, at the country or at the household level.

Author Contributions: Conceptualisation: R.O. and M.K.A. Data curation: A.O. Formal analysis: B.A. and J.A. Investigation: D.I.G. and M.Y.-P.P. Methodology: R.O.; Writing-original draft, R.O. Writing-review \& editing, A.O. All authors have read and agreed to the published version of the manuscript.

Funding: This research received no external funding.

Institutional Review Board Statement: Not applicable.

Informed Consent Statement: Not applicable.

Data Availability Statement: Not applicable.

Acknowledgments: The third, fourth and fifth authors acknowledge the equipment subsidy grant from the Alexander von Humboldt Foundation [REF: 3.4-8151/19047] awarded to the Centre for Economic Policy and Development Research (CEPDeR), Covenant University, Ota.

Conflicts of Interest: The authors declare no conflict of interest. 


\section{References}

1. World Bank. Agriculture and Food, World Bank Group, Washington DC, USA. 2020. Available online: https://www.worldbank. org/en/topic/agriculture/ overview (accessed on 30 September 2020).

2. Agrilinks Team. The Fourth Industrial Revolution and Its Potential Applications in Agriculture in Africa. Available online: https://www.agrilinks.org/post/fourth-industrial-revolution-and-its-potential-applications-agriculture-africa (accessed on 26 February 2020).

3. World Bank. Digital Dividends. World Development Report 2016 Washington, DC. Available online: http: / / documentsworldba nkorg/curated/en/896971468194972881/pdf/102725-PUB-Replacement-PUBLICpdf (accessed on 16 July 2020).

4. Beegle, K.; Christiaensen, L.; Dabalen, A.; Gaddis, I. Poverty in a Rising Africa; World Bank: Washington, DC, USA, 2016. [CrossRef]

5. Matthew, O.A.; Osabohien, R.; Ogunlusi, T.O.; Edafe, O. Agriculture and social protection for poverty reduction in ECOWAS. Cogent Arts Humanit. 2019, 6, 1682107. [CrossRef]

6. Osabohien, R.; Olurinola, I.; Matthew, O.; Ufua, D.E. Social protection intervention and agricultural participation in West Africa. Afr. J. Sci. Technol. Innov. Dev. 2020, 1-6. [CrossRef]

7. FAO. FAO's Work on Agricultural Innovation; Food and Agriculture Organization of United Nations (FAO): Rome, Italy, 2018.

8. World Bank. What Do We Mean by Social Inclusion? In Inclusion Matters: The Foundation for Shared Prosperity; World Bank: Washington, DC, USA, 2013; pp. 49-65. [CrossRef]

9. United Nations Department of Economic and Social Affairs. Identifying social inclusion and exclusion in the Report on the World Social Situation; United Nations Department of Economic and Social Affairs: New York, NY, USA, 2016; pp. 17-32. [CrossRef]

10. Jolley, E.; Lynch, P.; Virendrakumar, B.; Rowe, S. Education and social inclusion of people with disabilities in five countries in West Africa: A literature review. Disabil. Rehabil. 2018, 40, 2704-2712. [CrossRef] [PubMed]

11. Joshua, M. Food Security a Resource for Growth and Development in Nigeria. Masara 2015, 19, 381-391.

12. Dauda, R.O.S. Food Security: A Critical Variable in Nigeria's Quest for Economic Empowerment and Development. Ph.D Thesis, Department of Economics, University of Lagos, Akoka, Yaba, Lagos, Nigeria, 2006.

13. Shear, H.E. A Regional Approach to Analysis of Food Security Framework and Policies of the Economic Community of West African States (ECOWAS); University of Arkansas: Fayetteville, AR, USA, 2015.

14. Hidrobo, M.; Hoddinott, J.; Kumar, N.; Olivier, M. Social Protection, Food Security, and Asset Formation. World Dev. 2018, 101, 88-103. [CrossRef]

15. Subramaniam, Y.; Masron, T.A.; Azman, N.H.N. The impact of biofuels on food security. Int. Econ. 2019, 160, 72-83. [CrossRef]

16. Osabohien, R.; Matthew, O.; Olurinola, I.; Aderounmu, B. Agricultural transformation, youth participation and foodsecurity in Nigeria. AIMS Agric. Food 2020, 5, 911-919. [CrossRef]

17. Lee, G.O.; Surkan, P.J.; Zelner, J.; Paredes Olórtegui, M.; Peñataro Yori, P.; Ambikapathi, R.; Caulfield, L.E.; Gilman, R.H.; Kosek, M.N. Social connectedness is associated with food security among peri-urban Peruvian Amazonian communities. SSM Popul. Health 2018, 4, 254-262. [CrossRef]

18. Fiaz, S.; Noor, M.A.; Aldosri, F.O. Achieving food security in the Kingdom of Saudi Arabia through innovation: Potential role of agricultural extension. J. Saudi Soc. Agric. Sci. 2018, 17, 365-375. [CrossRef]

19. Zhang, Y.; Geng, W.; Shen, Y.; Wang, Y.; Dai, Y.C. Edible mushroom cultivation for food security and rural development in China: Bio-innovation, technological dissemination and marketing. Sustainability 2014, 6, 2961-2973. [CrossRef]

20. Dutta, S. The Global Innovation Index 2017. Innovation Feeding the World. Available online: https://www.wipo.int/edocs/pub docs/en/wipo_pub_gii_2017.pdf (accessed on 16 July 2020).

21. Khan, Z.R.; Midega, C.A.O.; Pittchar, J.O.; Murage, A.W.; Birkett, M.A.; Bruce, T.J.A.; Pickett, J.A.; Jo, P.; Aw, M.; Ma, B.; et al. Achieving food security for one million sub-Saharan African poor through push-pull innovation by 2020. Philos. Trans. R. Soc. B Biol. Sci. 2014, 369, 20120284. [CrossRef]

22. Bettencourt, L.; West, G. A unified theory of urban living. Nature 2010, 467, 912-913. [CrossRef] [PubMed]

23. Di Vaio, A.; Flavio, B.; Loris, L.; Rosa, P. Artificial intelligence in the agri-food system: Rethinking sustainable business models in the COVID-19 scenario. Sustainability 2020, 12, 4851. [CrossRef]

24. Grieve, B.D.; Tom, D.; Martin, C.; Lesley, B.; Jon, W.; Hujun, Y.; Farshad, A.; Simon, P. The challenges posed by global broadacre crops in delivering smart agri-robotic solutions: A fundamental rethink is required. Glob. Food Secur. 2019, 23, 116-124. [CrossRef]

25. Vinuesa, R.; Hossein, A.; Iolanda, L.; Madeline, B.; Virginia, D.; Sami, D.; Anna, F.; Simone Daniela, L.; Max, T.; Francesco, F.N. The role of artificial intelligence in achieving the Sustainable Development Goals. Nat. Commun. 2020, 11, 233. [CrossRef]

26. Ogunniyi, A.I.; Mavrotas, G.; Olagunju, K.O.; Fadare, O.; Adedoyin, R. Governance quality, remittances and their implications for food and nutrition security in Sub-Saharan Africa. World Dev. 2020, 127, 104752. [CrossRef]

27. Arellano, M.; Bond, S. Some tests of specification for panel data: Monte Carlo evidence and an application to employment equations. Rev. Econ. Stud. 1991, 58, 277-297. [CrossRef]

28. Windmeijer, F. A finite sample correction for the variance of linear efficient two-step GMM estimators. J. Econom. 2005, $126,25-51$. [CrossRef]

29. World Bank. Country Policy and Institutional Assessment (CPIA), World Development Indicators (WDI), and World Governance Indicators (WGI) Databases; World Bank Group: Washington, DC, USA, 2019.

30. Olofin, O.P.; Olufolahan, T.J.; Jooda, T.D. Food security, income growth and government effectiveness in West African countries. Eur. Sci. J. 2015, 11, 417-429. 
31. Djokoto, J. Effects of Foreign Direct Investment Inflows into Agriculture on Food Security in Ghana. Int. J. Innov. Sustain. Dev. 2012, 3, 81-92.

32. Slimane, M.B.; Huchet, M.; Zitouna, H. Direct and indirect effects of FDI on food security: A sectoral approach. In Workshop MAD Macroeconomics of Agriculture and Development_What Challenges Food Security? 2013 UMR Structures et Marchés Agricoles, Ressources et Territoires (1302); Institut National de Recherche Agronomique (INRA): Rennes, France, 2013; 27p.

33. Blundell, R.; Bond, S. Initial conditions and moment restrictions in dynamic panel data models. J. Econom. 1998, 87, 115-143. [CrossRef] 